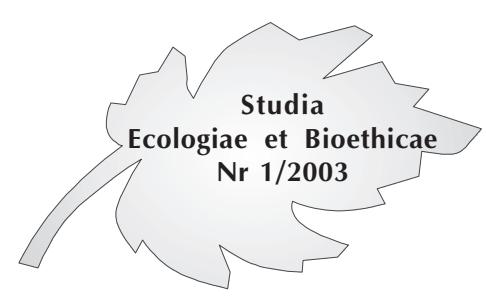

Maryla AFTANASIUK*

\title{
Sprawność fizyczna dzieci wiejskich i miejskich z niskiej grupy społeczno-ekonomicznej na Jukatanie (Meksyk)
}

\begin{abstract}
Wstęp
Celem niniejszej pracy jest porównanie sprawności fizycznej dzieci szkolnych zamieszkujących wieś i miasto, wywodzących się z niskiej grupy społeczno-ekonomicznej. Badania takie maja zasadnicze znaczenie dla zrozumienia mechanizmów kształtowania się motoryki człowieka w zależności od warunków środowiskowych i trybu życia, a szczególnie ograniczenia aktywności ruchowej, jaka niesie ze sobą współczesna cywilizacja wysoko uprzemysłowionych społeczeństw.

W niniejszej pracy weryfikowano następującą hipotezę roboczą: Rozwój fizyczny dzieci miejskich, mieszkających w Meridzie jest lepszy niż dzieci wiejskich, pochodzących z Yaxcaba, co wynika głównie z podaży żywności, bardziej urozmaiconej w mieście niż na wsi. U dzieci miejskich wyniki testów sprawnościowych bardziej złożonych (większa ilość jednostek motorycznych bierze udział $\mathrm{w}$ przejawie danej cechy) będą lepsze niż u dzieci wiejskich. Natomiast należy oczekiwać, że testy mniej złożone powinny być lepiej wykonane przez dzieci wiejskie niż miejskie.
\end{abstract}

\section{Material i metoda}

Materiał niniejszej pracy obejmuje 552 dzieci zamieszkujących miasto Meridę i 526 dzieci zamieszkujących wieś gminną Yaxcaba, położonych na Półwyspie Jukatan w Meksyku. Przebadano łącznie 1078 dzieci (537 chłopców i 541 dziewcząt). Dzieci pochodziły z dwóch grup etnicznych Majów i Metysów oraz Kreoli. We wsi Yaxcaba przebadano 460 Majów i Matysów oraz 66 dzieci z grupy etnicznej Kreoli. Natomiast w Meridzie przebadano 405 dzieci Maja i Metysów oraz 147 Kreoli.

\footnotetext{
Praca magisterska napisana pod kierunkiem Prof. UKSW, dr hab. Anny Siniarskiej-Wolańskiej.
} 
Dzieci podzielono wg płci na osiem, rocznych grup wiekowych od 7 $(6,5-7,49)$ do $14(13,5-14,49)$ roku życia.

Zarówno dzieci miejskie (z Meridy) jak i wiejskie (z Yaxcaba ) pochodzą z niskiej grupy społeczno-ekonomicznej. Dzieci miejskie badane były w trzech szkołach, zlokalizowanych w biednej, północnej dzielnicy Meridy, zwanej Chuburna. Merida jest stolicą stanu Jukatan w Meksyku. Miasto to, położone jest ok. $30 \mathrm{~km}$ na południe od Zatoki Meksykańskiej. Yaxcaba natomiast jest wsią gminną stanu Jukatan, zlokalizowaną $113 \mathrm{~km}$ na wschód od Meridy, w kierunku znanego stanowiska archeologicznego i starego miejsca kultury Majów, a od X wieku i Totleków - Chichen Itza. Wg oficjalnych danych wieś tę zamieszkuje 2558 osób i większość zajmuje się rolnictwem, hodowlą i pszczelarstwem.

Badania, będące podstawą niniejszej pracy wykonane zostały metodą przekrojową w latach 1996-1997 w Meridzie i 1999-2000 w Yaxcaba, w ramach projektu CONACyT nr. $26469 \mathrm{H}$, kierowanego przez prof. dr hab. Napoleona Wolańskiego. $\mathrm{W}$ trakcie wykonywania badań uczestniczyły te same osoby oraz pomiar cech miał miejsce w godzinach przedpołudniowych.

Do celów niniejszej pracy wzięto pod uwagę informacje ankietowe dotyczące wieku, płci, i grupy etnicznej dzieci, pomiary trzech cech somatycznych: wysokości, masy ciała i obwodu ramienia (w miejscu gdzie jest największy) oraz rezultaty niektórych testów sprawnościowych służące do oceny sprawności fizycznej.

Pomiar wysokości ciała wykonano zgodnie z ogólnie przyjętą techniką (Martin i Saller 1957-59). Sprawność fizyczną oceniono na podstawie pięciu testów (Pawlak i Sarna 1982) mierzących siłę statyczną ręki dominującej za pomocą dynamometru ręcznego, siłę eksplozywną kończyn dolnych (wyskok Sargenta), zwinność w biegu po ósemce, gibkość kręgosłupa (przy pomocy przyrządu Groszenkowa-Wolańskiego; Wolański 1975) oraz szybkość reakcji (refleks) za pomocą linijki (Quickstick scale).

W każdym przypadku badany był oswajany z przyrządami i przyuczany do wykonania testu. Wykonywał właściwą próbę dopiero po zapoznaniu się z jej prawidłowym przebiegiem.

Obliczenia statystyczne wykonano przy użyciu pakietu statystycznego SPSS. Do oszacowania różnic istotnych statystycznych wykorzystano test T Studenta.

Kolejnym etapem pracy była ocena wpływu czterech niezależnych czynników: regionu, płci, grupy etnicznej i wieku na badane cechy somatyczne i sprawnościowe. Do tego celu użyto czteroczynnikowej analizy wariancji. Czynnik "region” jest związany z miejscem pochodzenia dzieci, czyli z miastem i wsią. Nazwany został czynnikiem środowiskowym, gdyż jest związany z różnym trybem życia, odmiennym stopniem urbanizacji i zanieczyszczenia środowiska, różnymi rodzajami wykonywanej pracy itp. Czynnik „wiek" przyjęto jako odpowiednik czynnika genetycz- 
nego, gdyż jest związany ze zmianami rozwojowymi zachodzącymi $\mathrm{w}$ badanym okresie ontogenezy. Czynnik „płeć” można przyjąć za czynnik genetyczno-środowiskowy. Wiadomo, że płeć, choć jest uwarunkowana genetycznie, zależy także od różnic w zachowaniach społecznych oraz aktywności fizycznej. Czynnik "grupa etniczna" można nazwać kulturowo-genetycznym. Jego genezą jest odmienność genetyczna, lecz z grupa etniczną mogą wiązać się różne zwyczaje kulturowe, inny rodzaj żywienia i tryb życia. Można się tu także doszukiwać pewnej odmiennej ekspresji genów, mającej swe korzenie wiele tysięcy lat temu.

\section{Analiza wyników własnych}

\section{Budowa ciała i sprawność fizyczna dzieci z Méridy i Yaxcabá}

Porównanie dzieci mieszkających na wsi (Yaxcabá) z dziećmi mieszkającymi w mieście (Mérida) dało następujące rezultaty:

Pod względem wysokości wyższe dzieci zamieszkują miasto niż wieś. Istotne różnice statystyczne dla chłopców występują w wieku: 9, 10, 11 i 12 lat a dla dziewcząt w wieku 10, 12 i 13 lat (Ryc. 1).

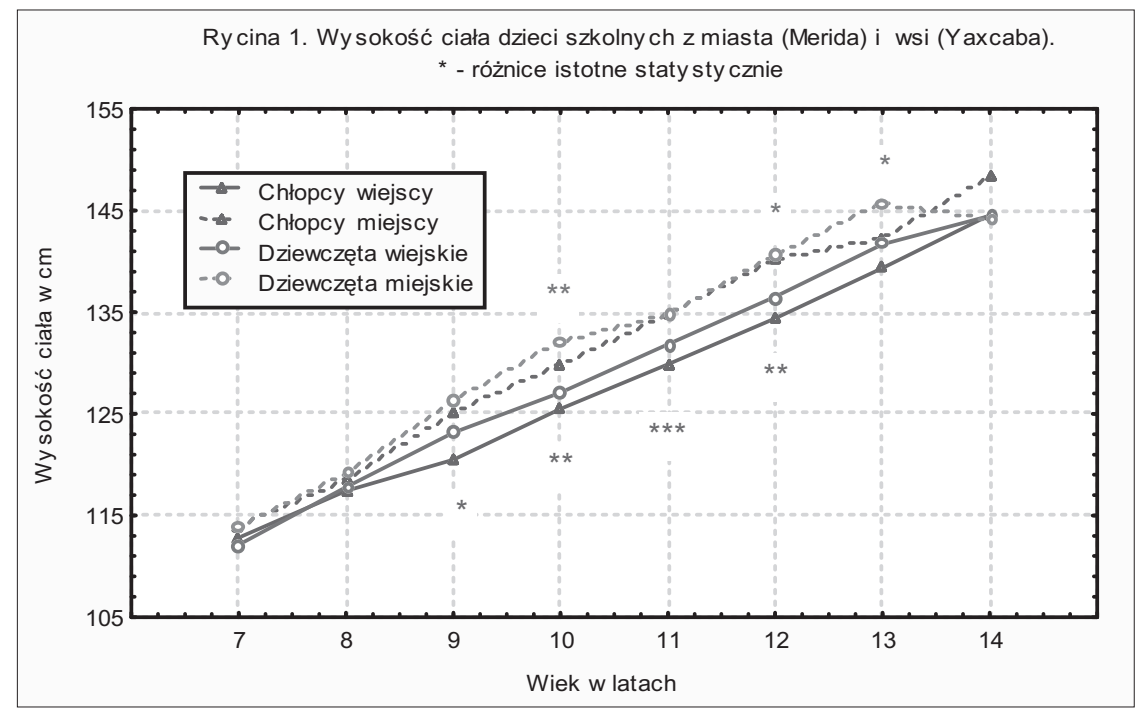

Wskaźnik masywności ciała zwany także wskaźnikiem Kaupa (BMI) nie wykazuje różnic istotnych statystycznie między dziećmi miejskimi i wiejskimi z wyjątkiem 11-letnich dziewcząt, u których względna masa ciała jest większa $\mathrm{w}$ mieście niż na wsi. Jednakże $\mathrm{z}$ tendencji przebiegu krzywych można również wnioskować, że dzieci miejskie w wieku 9-11 lat są nieco bardziej masywne niż wiejskie (Ryc. 2). 


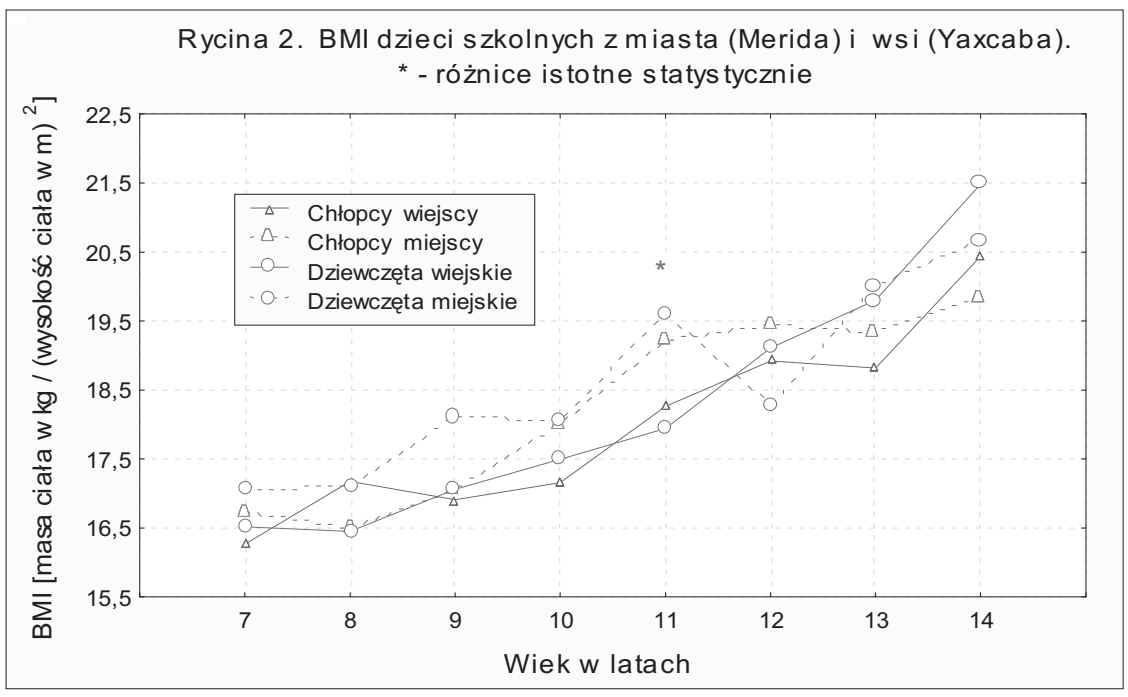

W przypadku obwodu ramienia, będącego miarą stanu odżywienia, w zasadzie nie stwierdzono różnic istotnych statystycznie między dziećmi wiejskimi i miejskimi, z wyjątkiem 13-letnich chłopców, u których ta cecha jest większa w mieście. Można jednakże zauważyć, że chłopcy miejscy w wieku 10-13 lat mają nieco większy obwód ramienia niż wiejscy. To samo dotyczy dziewcząt w wieku 7-11 lat (Ryc. 3)

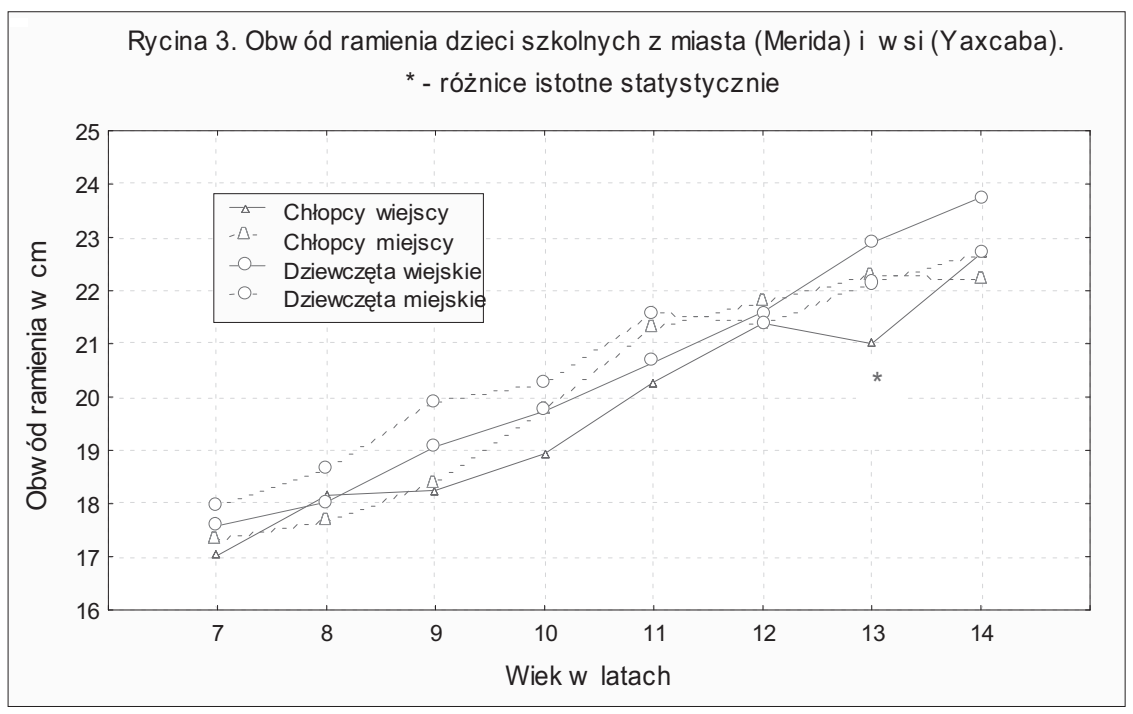

Większą siłą mięśniową ręki dominującej charakteryzują się chłopcy wiejscy niż miejscy, choć różnice istotne statystycznie występują tylko w 
wieku 10, 11, 14 lat. Również dziewczęta wiejskie są silniejsze niż miejskie, a istotne różnice statystyczne występują w wieku 10 i 14 lat (Ryc. 4).

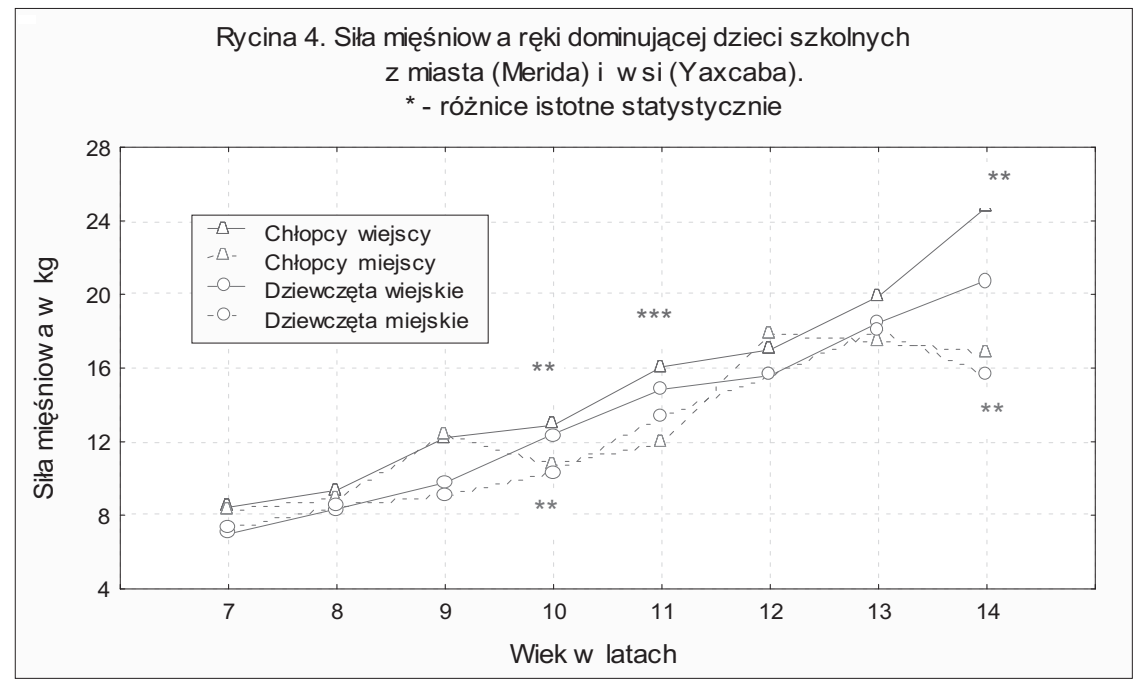

W przypadku zwinności mierzonej biegiem po ósemce, dzieci miejskie charakteryzują się krótszym czasem przebiegu niż wiejskie. Różnice istotne statystycznie są widoczne u chłopców w wieku 8, 10, 11 i 12 lat; zaś dla dziewcząt w wieku 9, 10 i 13 lat (Ryc. 5). W tym przypadku sprawniejsze (bardziej zwinne) są więc dzieci miejskie.

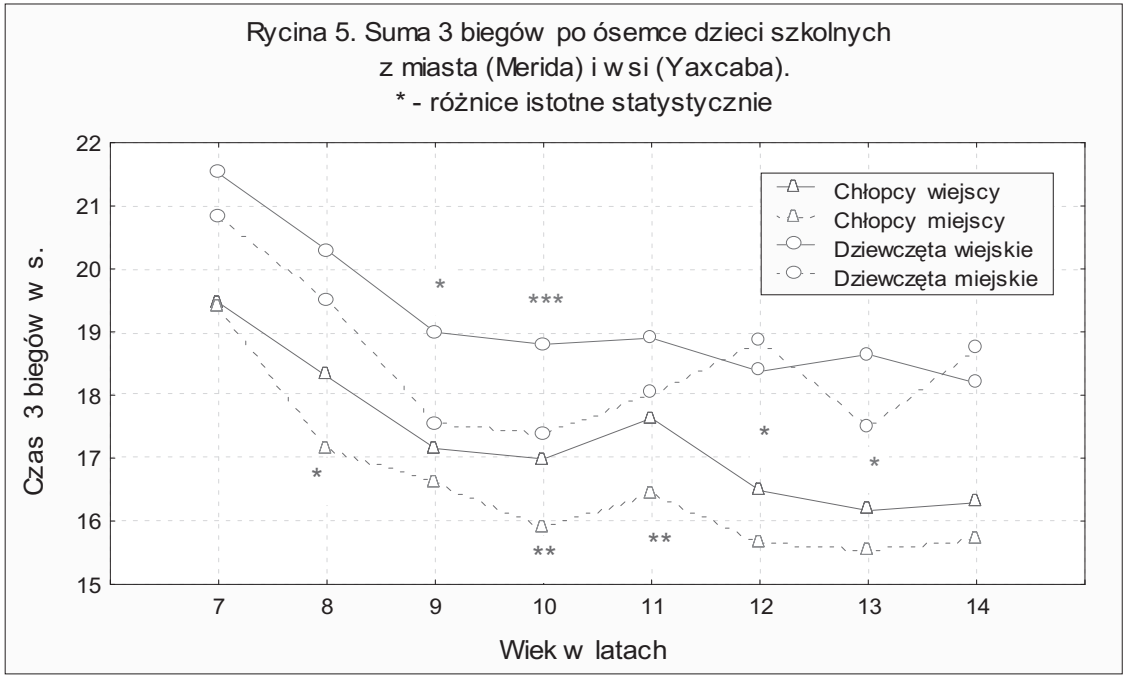

Ocena wskaźnika wyskoku dosiężnego metodą Sargenta w zasadzie nie wykazała różnic istotnych statystycznie miedzy dziećmi szkolnymi z 
miasta i ze wsi. Tendencja przebiegu krzywych wskazuje jednak również, że od 11 roku życia dzieci wiejskie charakteryzują się większą siłą eksplozywną kończyn dolnych niż dzieci miejskie. Jedyne różnice istotne statystycznie obserwuje się u chłopców w 11 roku życia (Ryc. 6).

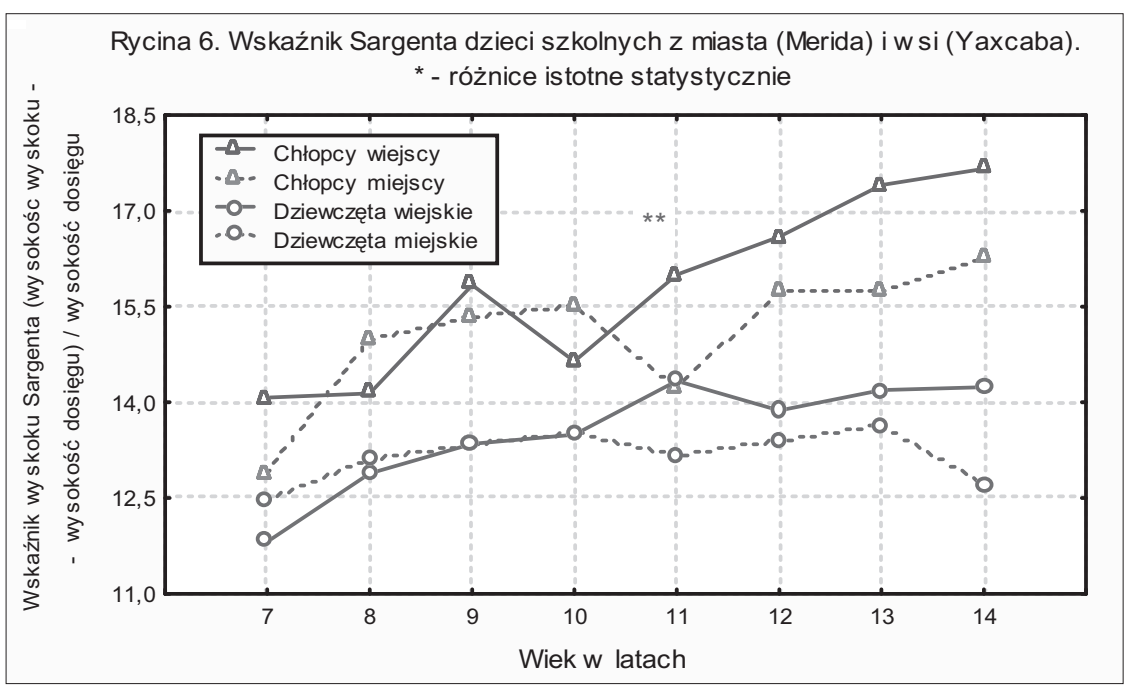

Podobnie jest z gibkością kręgosłupa. Obserwacja tendencji przebiegu krzywych dla tej cechy wskazuje na większą gibkość dzieci wiejskich (z wyjątkiem dziewcząt 9 i 10- letnich, które są bardziej gibkie w mieście). Różnice istotne statystycznie widoczne są jedynie u 7-letnich chłopców. Cecha ta wykazuje również znaczny dymorfizm płciowy i zauważa się dużo większą gibkość kręgosłupa u chłopców niż u dziewcząt (Ryc. 7).

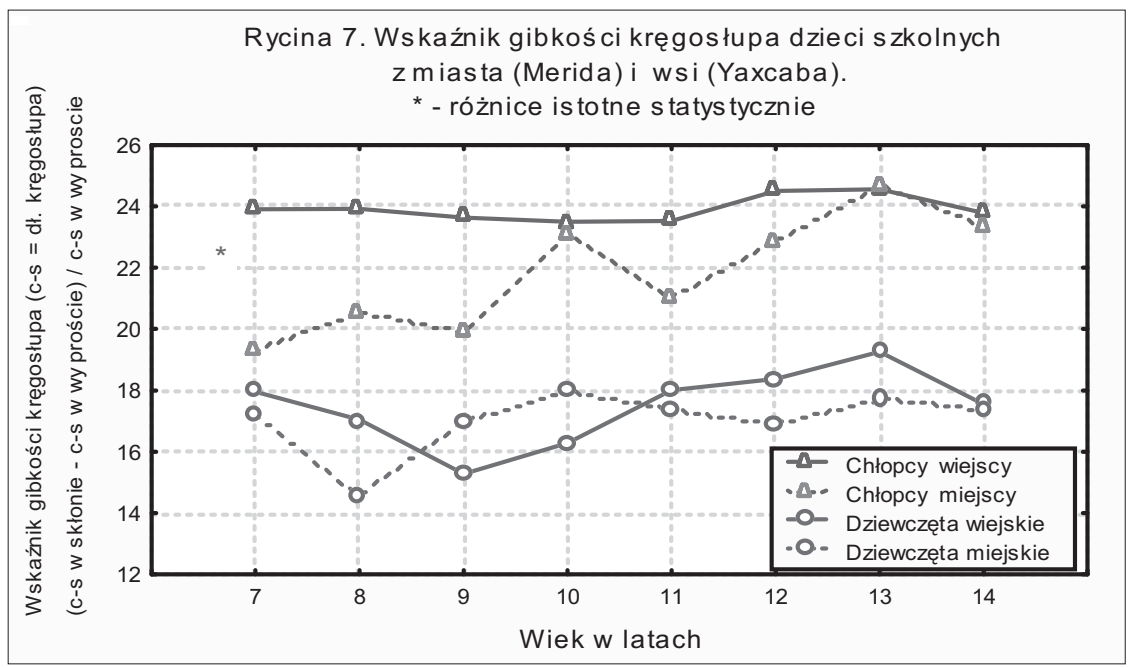


Porównując szybkość reakcji, mierzoną w punktach (więcej punktów gorszy wynik), okazuje się, że po 9 roku życia chłopcy wiejscy osiągają lepsze wyniki niż miejscy. Różnice istotne statystycznie występują u chłopców 11, 13 i 14-letnich. U dziewcząt obserwuje się podobną tendencję, z tym, ze różnice istotne statystycznie są zaznaczone jedynie w 11 roku życia (Ryc. 8).

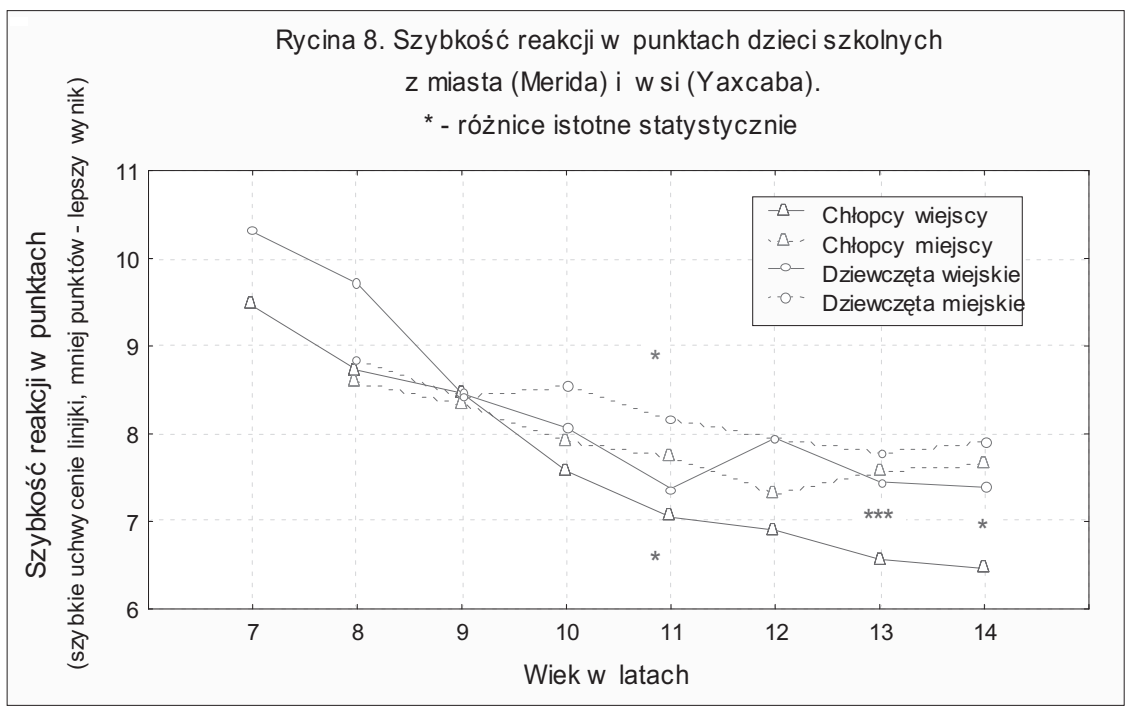

Wyżej wymienione wyniki wskazują na większą sprawność fizyczną zarówno chłopców jak i dziewcząt wiejskich (z Yaxcaba) niż miejskich (Merida), z wyjątkiem zwinności w biegu. Dzieci mieszkające na wsi, mimo gorszego rozwoju fizycznego (niższe i lżejsze) mają większą gibkość kręgosłupa, charakteryzują się większą siłę statyczną i eksplozywną oraz lepszą szybkością reakcji niż dzieci zamieszkujące miasto. Ich gorsza zwinność w biegu może wynikać z innego trybu życia. Dzieci miejskie mają ponad to ćwiczenia ruchowe (wychowanie fizyczne) w szkołach, których często brak jest w szkołach wiejskich nie posiadających odpowiednich sal i przyrządów, natomiast praca w polu i gospodarstwie raczej zwinności nie wyrabia.

\section{Ocena wpływu czynników środowiskowych i genetycznych na cechy budowy ciała i sprawność fizyczną}

Zastosowanie wieloczynnikowej analizy wariancji wykazało, że cztery czynniki (region, płeć, wiek i grupa etniczna) wyjaśniają znaczną część całkowitej zmienności badanych cech, bardziej cech budowy ciała i nieco mniej cech sprawnościowych (Tab. 1) 
Maryla Aftanasiuk

Tabela 1. Czteroczynnikowa analiza wariancji cech somatycznych i sprawnościowych u dzieci szkolnych w Yaxcaba (wieś) i Meridzie (miasto).

\begin{tabular}{|l|l|l|l|l|c|}
\hline \multirow{2}{*}{$\begin{array}{l}\text { Cechy somatyczne } \\
\text { i motoryczne }\end{array}$} & \multicolumn{4}{|c|}{ Czynniki (F) } & \multirow{2}{*}{$\mathrm{R}^{2}$} \\
\cline { 2 - 5 } & Region (F1) & Płeć (F2) & $\begin{array}{l}\text { Grupa etni- } \\
\text { czna (F3) }\end{array}$ & $\begin{array}{l}\text { Grupa } \\
\text { wieku (F4) }\end{array}$ & \\
\hline Wysokość ciała & $13,61^{* * *}$ & 0,45 & $20,94^{* * *}$ & $190,8^{* * *}$ & 0,734 \\
Masa ciała & 3,83 & 1,71 & $11,17^{* *}$ & $91,88^{* * *}$ & 0,578 \\
Wskaźnik BMI & 0,70 & 2,46 & 3,63 & $16,85^{* * *}$ & 0,244 \\
Obwód ramienia & 0,14 & $5,50^{*}$ & $5,45^{*}$ & $39,15^{* * *}$ & 0,406 \\
Siła mięśniowa & $13,24^{* * *}$ & $19,40^{* * *}$ & $10,32^{* * *}$ & $65,22^{* * *}$ & 0,529 \\
Suma biegów po ósemce & $6,30^{*}$ & $83,43^{* * *}$ & 1,40 & $26,71^{* * *}$ & 0,394 \\
Wskaźnik Sargenta & 2,23 & $47,94^{* * *}$ & 2,05 & $8,55^{* * *}$ & 0,214 \\
Wskaźnik gibkości & 3,36 & $36,05^{* * *}$ & 0,004 & 1,43 & 0,162 \\
kręgosłupa & & $13,87^{* * *}$ & 2,834 & $12,31^{* * *}$ & 0,250 \\
Szybkość reakcji & $10,15^{* *}$ & 134 &
\end{tabular}

Legenda: Czynnik 1 (środowiskowy) - region (wieś - Yaxcaba, miasto - Merida); czynnik 2 (genetyczo-środowiskowy) - płeć badanych dzieci; czynnik 3 (kulturowo-genetyczny) Majowie i Metysi oraz Kreole; czynnik 4 (genetyczny) - wiek badanych dzieci. *- p<0,05; $* *-\mathrm{p}<0,01 ; * * *-\mathrm{p}<0,001$.

W przypadku wysokości ciała wspomniane 4 czynniki wyjaśniają $73,4 \%$ całkowitej jej zmienności, dla masy ciała - 57,8\%, dla siły mięśniowej - 52,9\%, dla obwodu ramienia - 40,6\%, dla zwinności w biegu $39,4 \%$, dla szybkości reakcji - $25 \%$, dla BMI - $24,4 \%$, oraz najniższy procent wyjaśnianej zmienności dotyczy siły eksplozywnej kończyn dolnych - 21,4\% i gibkości kręgosłupa - 16,2\%.

Wpływ poszczególnych czynników jest więc różny w zależności od badanej cechy. Czynnik wieku (rozwojowo-genetyczny) jest najsilniej związany z badanymi cechami. Wiadomo, że wraz z wiekiem, co jest głównie uwarunkowane genetycznie, wielkości cech ulegają zmianie. Wszystkie badane cechy ulegają rozwojowi progresywnemu, co oznacza zwiększenie wymiarów i masy ciała oraz siły statycznej i eksplozywnej; natomiast także zmianą progresywną (lepszym wynikiem) jest krótszy czas, a więc większa szybkość w biegu zwinnościowym oraz krótszy czas reakcji. Wszystkie też wymienione cechy są silnie uwarunkowane czynnikiem wieku. Wyjątkiem jest gibkość kręgosłupa, która rozwija się głównie w młodszym wieku niż brane pod uwagę dzieci, zaś u dzieci 7-14 letnich cecha ta nie ulega większej zmianie, po którym to okresie następuje jej regres.

Czynnik zawiązany z płcią badanych dzieci, oceniający nie tylko związane $\mathrm{z}$ tym różnice genetyczne, ale być może przede wszystkim różnice w aktywności fizycznej miedzy chłopcami i dziewczętami, wykazuje głównie związek z cechami sprawnościowymi oraz słabszy związek z obwodem ramienia. 
Sprawność fizyczna dzieci wiejskich i miejskich z niskiej grupy społeczno-ekonomicznej ...

Czynnik środowiskowy (wieś - miasto) wskazuje na związek z wysokością ciała, siłą mięśniową, szybkością reakcji i nikły ze zwinnością w biegu.

Czynnik kulturowy (grupa etniczna) jest natomiast związany z wysokością i masą ciała oraz statyczną siłą mięśniową, w nikłym stopniu z obwodem ramienia mierzącym rozwój mięśni oraz stan odżywienia.

\section{Dyskusja wyników}

Hipoteza badawcza niniejszej pracy oparta o przewidywania wynikające z dotychczasowych badań zakładała, że dzieci szkolne z miasta Meridy będzie cechował lepszy rozwój fizyczny niż ma to miejsce na wsi (Yaxcaba), natomiast że dzieci wiejskie będą osiągały lepsze rezultaty $\mathrm{w}$ tych cechach sprawnościowych, których przejaw jest prostszy czyli mniej jest zaangażowanych jednostek motorycznych (np. siła mięśniowa, wyskok dosiężny, gibkość kręgosłupa), podczas gdy dzieci miejskie będą dominowały $\mathrm{w}$ testach bardziej złożonych, szczególnie tam gdzie dane czynności są silnie związane z rozwojem układu nerwowego i wymagają koordynacji (zwinność w biegu, czas reakcji).

Wyniki badań potwierdziły pierwsze założenie, bowiem faktycznie rozwój fizyczny dzieci miejskich z Meridy, pod względem wysokości i masy ciała jest lepszy niż ma to miejsce $u$ dzieci wiejskich (z Yaxcaba). Wyniki takie są powszechnie znane, tak w przypadku rozwoju dzieci i młodzieży jak i dorosłych osobników z populacji wiejskich i miejskich $\mathrm{w}$ wielu zakątkach świata.

Po raz pierwszy w historii ludzkości, $\mathrm{z}$ końcem $\mathrm{XX}$ wieku ponad połowa ludzi na świecie żyła w mieście, a do 2020 roku będzie to aż $60 \%$ ludności (Bogin, 1999). Nadal w wielu miejscach świata warunki bytowe w mieście są zdecydowanie lepsze niż na wsi. Chodzi głównie o dostęp do różnorodnego pożywienia, lepsze warunki higieny, lżejszą pracę i bardziej urozmaicony tryb życia. Walory te, jeszcze w wielu państwach, przeważają nad zanieczyszczeniem środowiska i stresami życia codziennego coraz bardziej powszechnymi w miastach.

Merida, jest miastem, gdzie warunki bytowe są zdecydowanie lepsze niż w wioskach na terenie Jukatanu. Jest to miasto, gdzie dość łatwo dostać choćby dorywczą pracę, niezbyt zanieczyszczone, jednak o dużej dysproporcji między zamożnymi i ubogimi klasami społeczno-ekonomicznymi. Potwierdzeniem tego spostrzeżenia jest fakt, że dzieci z Meridy, które nie reprezentują całej populacji miejskiej gdyż pochodzą z niskiej klasy społeczno-ekonomicznej, wykazują rozwój fizyczny lepszy niż obserwowany u dzieci wiejskich. Także dzieci pochodzące z typowych wiosek uprawiających kukurydzę jak również sizal, są niższe i lżejsze od dzieci z wiosek trudniących się hodowlą bydła czy z terenów położo- 
nych blisko Zatoki Meksykańskiej, gdzie ludność trudni się rybołówstwem (Kelley, 1991; Murguia i wsp., 1991). Nawet dzieci z południowej części Meridy (biedniejszej) są słabiej fizycznie rozwinięte niż z północnej, zamożniejszej części tego miasta (Kelley, 1991, Wolański i wsp., 1993).

Pozostałe założenia niniejszej rozprawy dotyczące rozwoju sprawności fizycznej nie w pełni uległy potwierdzeniu. Wyniki większości testów, w tym szybkości rekcji (refleksu) są lepsze u dzieci wiejskich niż miejskich. Jedynie zwinność mierzona czasem biegu po ósemce, która jest testem raczej złożonym (koordynacja neuromięśniowa) jest lepsza u dzieci miejskich.

$\mathrm{Z}$ literatury wiadomo, że w złych warunkach społeczno-ekonomicznych gorszemu rozwojowi somatycznemu chłopców towarzyszyły lepsze wyniki w testach sprawnościowych (Pařizková i Merhautova; 1970, Siniarska i Wolański, 2000; Hennenberg i Louw, 1998). Zjawisko to wskazuje, ze rozwój somatyczny i sprawnościowy może być wynikiem przystosowania do lokalnych warunków życia, w tym żywienia i aktywności fizycznej (Malina, 1984). Badania prowadzone w Estonii wykazały, że rozwój cech somatycznych (długościowych i szerokościowych kośćca) nie jest zależny od stopnia aktywności dzieci. Jedynie masa ciała i tkanka tłuszczowa były ujemnie skorelowane ze stopniem aktywności dzieci (Raudsepp i Päll, 1999).

Zastanawiający jest rezultat testu badającego szybkość reakcji (refleks). Test ten wymaga większego zaangażowania układu nerwowego i szczególnego skoncentrowania się na jego wykonaniu. Z postawionej w tejże pracy hipotezie roboczej należało się spodziewać lepszych wyników tego testu u dzieci miejskich. Otóż badania pokazały, że lepsze rezultaty osiągnęły dzieci zamieszkujące wieś, czyli dzieci charakteryzujące się słabszym rozwojem fizycznym. Trudno powiedzieć, czy zjawisko to można tłumaczyć mniej stresowym trybem życia i mniejszym obciążeniem umysłowym dzieci wiejskich. W badaniach polskich, dzieci miejskie osiągnęły w podobnym, (ale nie tym samym) teście na szybkość reakcji lepsze rezultaty w porównaniu z dziećmi wiejskimi i z terenów uprzemysłowionych (Elżanowska i Siniarska, 1982). Wyniki tego samego, co w niniejszej pracy, testu na refleks w Południowej Afryce też były lepsze u dzieci miejskich niż wiejskich (Henneberg i Louw, 1998). Być może sytuacja występująca na Jukatanie dotyczy jedynie dzieci miejskich z niskiej klasy społeczno-ekonomicznej, które nie reprezentują całej populacji miejskiej.

Wynikiem potwierdzającym hipotezę roboczą jest natomiast wynik testu badającego jeden z aspektów motoryczności - zwinność, przejawiającą się w szybkości biegu po torze w układzie ósemki (lepsze rezultaty $\mathrm{w}$ Meridzie niż w Yaxcaba). Test ten polega nie tylko na szybkim przebiegu, ale wymaga od badanego ciągłego myślenia o torze biegu i znacznej koordynacji ruchów. W Polsce, lepsze rezultaty tego testu (krótszy czas przebiegu) uzyskały także dzieci miejskie w porównaniu z wiejskimi (Elżanowska i Siniarska, 1982). Dzieci miejskie z Jukatanu podchodziły do 
Sprawność fizyczna dzieci wiejskich i miejskich z niskiej grupy społeczno-ekonomicznej ...

tego testu z większym entuzjazmem. Traktowały go jak rodzaj zawodów sportowych, pojawił się więc element współzawodnictwa, co mogło wpłynąć na lepsze wyniki. Dzieci na wsi osiągnęły słabsze wyniki być może z powodu zupełnego braku takiej motywacji.

Analizując poszczególne rezultaty testów sprawnościowych zauważyć można wyraźny dymorfizm płciowy przejawiający się szczególnie przy ocenie takich cech jak: siła mięśniowa, zwinność w biegu, siła eksplozywna oraz gibkość kręgosłupa, które to wyniki są zdecydowanie lepsze u chłopców w porównaniu z dziewczętami. Poza genetycznymi determinantami związanymi z płcią, co pociąga za sobą różnice w budowie i proporcjach ciała, różna jest także aktywność fizyczna chłopców i dziewcząt. Często ma także miejsce upodobnienie się pod względem sprawności fizycznej rodzeństwa różnej płci oraz zaznacza się także znaczący wpływ rodziny i szkoły na skutek podobnego trybu życia i nawyków (Malina i Moriyama, 1991).

Ostatni etap niniejszej dyskusji dotyczy wyników czteroczynnikowej analizy wariancji. Czynnik "wiek” jest związany z rozwojem ontogenetycznym, który znajduje się pod silną kontrolą genetyczną. Wszystkie cechy, które rozwijają się w trakcie ontogenezy są istotnie zależne od tego czynnika, co widoczne jest w Tabeli 1 . Od tej reguły wyłamuje się gibkość kręgosłupa, której intensywny rozwój przypada na nieco wcześniejszy wiek niż właściwy dla badanych tutaj dzieci, zaś w późniejszym wieku rozwój gibkości jest niewielki i dość wcześnie występuje jej regres.

Jeśli weźmiemy pod uwagę czynnik „region”, czyli te warunki środowiska zewnętrznego, które są specyficzne dla Meridy i dla Yaxcaba, a zarazem je różnicują, rezultaty są następujące. Zespół warunków różniących środowisko miejskie od wiejskiego wpływa na odmienność wysokość ciała badanych dzieci, siłę mięśniowa oraz szybkość reakcji (refleks). Mają więc one wpływ nie tylko na względnie prosty przejaw siły, ale i na złożony aspekt motoryczności, jakim jest szybkość reakcji.

Czynnik "płeć" to kompleksowe połączenie uwarunkowań genetycznych (genetyczna determinacja płci) oraz środowiskowych (inna aktywność fizyczna, różnice w nawykach i zachowaniu). Z wyjątkiem braku wpływu na wysokość i masę ciała oraz BMI, co jest zrozumiałe gdyż u dzieci 7-14 letnich dymorfizm płciowy pod względem tych cech jest jeszcze niewielki, czynnik płci znacząco wpływa na przejaw pozostałych cech, w tym wszystkich sprawnościowych. Dymorfizm płciowy jest więc silnie zaznaczony tak dla obwodu ramienia, jak i siły, szybkości i zwinności. Podobna analiza wariancji, choć trzy-czynnikowa została zastosowana przy porównaniu dzieci szkolnych z Meridy i Łodzi (też niska grupa społeczno-ekonomiczna). Istotny wpływ czynnika płci na wielkości cech sprawnościowych był podobny (Siniarska i wsp., 1998).

Ostatni czynnik stanowi grupa etniczna. Istnieją różnice genetyczne między Indianami Maja i Metysami oraz Kreolami, jak również pewne róż- 
nice kulturowe wpływające na sposób żywienia i tryb życia. Co do tych ostatnich różnic mogą być pewne zastrzeżenia, gdyż w niskiej grupie społeczno ekonomicznej, którą reprezentują Majowie, Metysi jak i Kreole, mogą być one zniwelowane lub ograniczone do minimum. $Z$ tabeli 1 wynika, że istotny wpływ tego czynnika jest widoczny w przypadku wysokości i masy ciała, obwodu ramienia oraz siły mięśniowej. Pozostałe cechy nie wykazują związku z tym czynnikiem. Wyniki analizy 3-czynnikowej między dziećmi z Meridy a Łodzi są dla czynnika "grupa etniczna" nieco inne (Siniarska i wsp., 1998). W tym przypadku różnice etniczne silnie oddziałują na wszystkie cechy sprawnościowe. Jest to spowodowane znacznie większymi różnicami, głównie kulturowymi, jak również trybem życia i żywieniem między Polską a Meksykiem niż między grupą Majów i Metysów a Kreolami, żyjącymi obok siebie na tym samym terenie.

$\mathrm{Na}$ zakończenie należy podkreślić, że siła mięśniowa jest jedynym przejawem sprawności fizycznej, na której wpływ mają wszystkie analizowane czynniki: wiek, region, płeć i grupa etniczna, jest to z drugiej strony cecha silnie związana zarówno z wielkością i masą ciała (a więc i mięśni) jak również z układem nerwowym (jednostkami neuromotorycznymi).

\section{Wnioski}

1. Dzieci miejskie z Meridy są wyższe, cięższe i charakteryzują się większym wskaźnikiem otłuszczenia niż dzieci wiejskie z Yaxcaba.

2. Mimo lepszego rozwoju fizycznego dzieci z miasta, lepszą sprawność fizyczną wykazują dzieci zamieszkujące wieś.

3. Dzieci wiejskie charakteryzują się większą siłą statyczną, eksplozywną kończyn dolnych oraz lepszą szybkością reakcji niż dzieci miejskie. Dzieci miejskie są natomiast zwinniejsze w biegu po ósemce.

4. Dymorfizm płciowy przejawia się szczególnie w przypadku siły eksplozywnej kończyn dolnych, gibkości kręgosłupa i siły mięśniowej ręki.

5. Czynnik środowiskowy "region” ma dużo większy wpływ na sprawność fizyczną niż czynnik genetyczno-kulturowy "grupa etniczna". Czynnik środowiskowy ma znaczący wpływ na wysokość ciała, siłę mięśniową i szybkość reakcji.

6. Wiek badanych dzieci, związany z silnie genetycznie kontrolowanym rozwojem ontogenetycznym, wpływa istotnie na wszystkie badane cechy tak somatyczne jak i sprawnościowe.

7. Czynnik genetyczno-kulturowy "grupa etniczna" znacząco wpływa na wysokość i masę ciała oraz siłę mięśniową.

8. Siła mięśniowa ręki dominującej jest jedynym przejawem sprawności fizycznej, na który wpływ mają wszystkie analizowane czynniki: wiek, region, płeć i grupa etniczna. 
Sprawność fizyczna dzieci wiejskich i miejskich z niskiej grupy społeczno-ekonomicznej ...

\section{Podziękowania}

Składam serdeczne podziękowania Pani prof.dr hab.Anny SiniarskiejWolańskiej za wszechstronną pomoc $\mathrm{w}$ napisaniu niniejszej pracy. Panu prof. dr hab. Napoleonowi Wolańskiemu dziękuję za udostępnienie materiału badawczego i bardzo cenne rady.

\section{Bibliografia}

Bogin B., 1999 - Patterns of Human Growth. Cambridge University Press, Cambridge.

ElŻANOWSKA D., SinIARSKA A., 1982 - Sprawność psychomotoryczna ludności z terenów o różnym stopniu uprzemysłowienia. [W:] Ekologia populacji ludzkich, red. N. Wolański i A. Siniarska, str. 667-705, Ossolineum, Wrocław.

Henneberg M., Louw G.J., 1998 - Cross-sectional survey of growth of urban and rural "Cape Coloured" schoolchildren: Anthropometry and functional tests. Amreican Journal of Human Biology, 10:73-85.

KeLLEY J.C.H., 1991 - Contrast in somatic variables among traditional and modernized Maya females. International Journal of Anthropology, 6(2):159-177.

Malina R., Moriyama M., 1991 - Growth and motor performance of Black and White children 6-10 years of age: A multivariate analysis. Am. J. Human Biol., 3:599-611.

Malina R., 1984 - Kinanthropometric research in human auxology. [W:] Human Growth and Development, red. J.Borms, R. Hauspie A. Sand C. Susanne i M. Hebbelinkc, str. 437-451, Plenum Press, New York.

Martin R., Saller K., 1957-59 - Lehrbuch der Anthropologie. G. Fischer Verlag, Stuttgart.

Murguia R., Dickinson F., Cervera D., Uc L., 1991 - Socio economic activities, ecology and somatic differences in Yucatan, Mexico. Studies in Human Ecology, 9:111-134.

PaŘizková J., Merhautova J., 1970 - The comparison of somatic development, body composition and functional characteristics in Tunisian and Czech boys of 11 and 12 years. Human Biol., 42(3):391-400.

PAWLAK K., SARNa J., Instrukcja do badań psychomotorycznych człowieka w problemie węzłowym 10.2. Ekologia populacji ludzkich, red. N. Wolański i A. Siniarska, str. 707-719, Ossolineum, Wrocław.

Raudsepp L., Päll P., 1999 - Physical growth and fatness as related to physical activity in preadolescent girls. Coll. Antropol., 23(1):53-58.

Siniarska A., Jeziorek A., Nowakowska M., 1998 - Physical fitenss of 7- to 14-year-old schoolchildren in Merida (Mexico) and Łódź (Poland). [W:] Physical Fitness and Nutrition During Growth, ed. by J. Pařizková i A.P. Hills, Medicine and Sport Science, 43, str. 27-43, Karger, Basel.

SiniarsKa A., Wolański N., 2000 - Grupy społeczne a budowa i funkcje organizmu mieszkańców Jukatanu. Scripta Periodica, III(2):421-432.

Wolański N., 1975 - Metody kontroli i normy rozwoju dzieci i młodzieży. PZWL, Warszawa.

Wolański N., Dickinson F., Siniarska A., 1993 - Biological traits and living conditions of Maya Indian and non Maya girls from Merida, Mexico. International Journal of Anthropology, 8(4):233-246. 


\title{
Physical fitness of urban and rural schoolchildren from low social strata in Yucatan, Mexico
}

\begin{abstract}
SUMMARY
Body build and physical fitness of schoolchildren of low socioeconomic strata from urban and rural areas of Yucatan were studied. The material consisted of 552 children from Merida (the capital city of Yucatan State, Mexico) and of 526 children from Yaxcaba horticultural community, 7 through 14 years of age. These are cross-sectional samples studied in 1996-97 in Merida and in 1999 and 2000 in Yaxcaba. The ethnic origin was evaluated using two surnames of children (from the father and mother side). The studied variables included stature, BMI, arm circumference, grip strength, agility run, Sargent vertical jump index (explosive strength), spine flexibility index and reaction time. Urban children are significantly taller than rural ones, and BMI and arm circumference show also a tendency to be greater in urban areas. Physical fitness tests are better performed (better results) in rural areas than in urban ones. If the whole material is divided according to two ethnic groups (Mayas and Mestizos, and Creoles) the differences in body build are still observed but those in physical fitness disappeared. Creole children are taller than Mayas and Mestizos and they show tendency to have more weight for height and greater arm circumference. Generally, the differences in physical fitness are only observed between rural and urban children what may be caused by more active way of life in villages than in towns resulting from an agricultural activity. However, differences in stature are observed between ethnic as well as between rural and urban groups. This may have the genetic origin (Creoles and Mayas), and in case of different localities it may also be caused by more various nutrition in towns than in villages.
\end{abstract}

